\title{
Role of the Serum Muscular Enzymes in the Diagnosis of Post-Exertional Rhabdomyolysis in Draft Horses Used in Transplant Rice Seedlings
}

\author{
Yasmin H. Bayoumi* \\ Animal Medicine Department (Internal Medicine), Faculty of Veterinary Medicine, Zagazig \\ University, 44511, Egypt
}

Article History: Received: 7/2/2018 Received in revised form: 23/2/2018 Accepted: 27/2/2018

\begin{abstract}
The present study was done to evaluate the role of serum muscular enzymes in the determination of the workload in healthy horses, and diagnosis of rhabdomyolysis (ER) cases. Twenty-one draft horses were assessed under the field conditions during rice seedling seasons. Animals were under complete history, physical examination and laboratory evaluation of serum muscular enzymes. Horses were categorized into 2 main groups; the first group, healthy horses under rice seedling work $(n=10)$. They were examined and sampled 4times/day work. The second group includes horses with exertional rhabdomyolysis under rice seedlings workload $(n=11)$ and they were examined and sampled on admission. Blood samples were collected and as a minimum, serum creatine kinase $(\mathrm{CK})$, lactate dehydrogenase $(\mathrm{LDH})$ and aspartate aminotransferase (AST) were evaluated. The obtained results clarified significant alterations in the vital signs in the exertional rhabdomyolysis group in comparison to healthy horses under the same workload in the four examination periods. Additionally, highly significant increase $(\mathrm{P} \leq 0.001)$ in serum $\mathrm{CK}$, LDH and AST levels in exertional rhabdomyolysis cases in comparison to the healthy horses and to the normal reference limits. While two or more folds increase in the serum muscular enzymes were recorded in healthy horses during workload and $4 \mathrm{~h}$ post-work when compared to the prework measurements. This, in turn, reflects the great load in healthy horses during rice seedling seasons.
\end{abstract}

Keywords: Draft Horses, Rhabdomyolysis, Rice Seedlings, CK, LDH, AST.

\section{Introduction}

Among equine diseases, rhabdomyolysis is considered one of the most serious and potentially life-threatening conditions. Previously, equine rhabdomyolysis was considered a single disease described as azoturia or tying-up, it now comprises several different myopathies, which, despite their similarities clinically, they differ significantly in their etiopathology [1]. Recent studies classified rhabdomyolysis in horse into exertional and non-exertional ones. Nonexertional myopathies could be attributed to a number of etiologies that cause significant muscle necrosis, including various infectious agents; viral infections (equine influenza), bacterial infections (Streptococcus equi subsp. equi), nutritional deficiencies (Vitamin $\mathrm{E}$ and Selenium deficiency), toxicities (ivermectin) and inherited (polysaccharide storage myopathy) [1-4]. Exertional rhabdomyolysis "exercise-induced rhabdomyolysis" has been of a rising concern [1,4]. Exertional rhabdomyolysis (ER) occurs in horses performing exercises beyond their conditioning status and in those performing strenuous exercises after a period of rest on full ration $[5,6]$.

In Egypt, draft horses are commonly used to provide draft power for preparation and leveling of the flood, wet-bed rice nurseries and transporting rice seedling in rice cultivation season. Exertional Rhabdomyolysis (ER) is mostly associated with the initiation of this hard work [6]. Recent studies have suggested that many contributing factors to sporadic ER as over-exertion (increase in work intensity without foundation), heat exhaustion (exercising in hot and humid weather), and dietary imbalances (high nonstructural carbohydrates in the diet, inadequate selenium and vitamin $\mathrm{E}$ and electrolyte imbalances) [7].

Diagnosis of ER was based on history and clinical signs, as horses typically exhibited stiff gait, excessive sweating, muscle cramp, increased respiratory and heart rates during or after exercise. Biochemically, myoglobinuria 
and moderate to marked elevations in levels of serum creatine kinase (CK), lactate dehydrogenase (LDH), and aspartate aminotransferase (AST) were characteristic, and muscle biopsy with histological lesions was diagnostic $[1,8,9]$.

Creatine kinase $(\mathrm{CK})$ in muscle is important for making Adenosine triphosphate (ATP) available for muscle contraction by the phosphorylation of Adenosine diphosphate (ADP) from creatine phosphate [10]. CK is liberated within few hours of muscle damage or increase the permeability of cell membrane into the extracellular fluid, and it reaches the peak within 4-6 h after the muscle injury [11].

Limited elevations in CK (1000 U/L) may accompany the training or the transport. Extremely exhausted exercise like endurance rides or the cross the country phase may result in serum CK activities being increased to 1000 $\mathrm{U} / \mathrm{L}$, but less than $5000 \mathrm{U} / \mathrm{L}$. Under these circumstances, serum $\mathrm{CK}$ activities rapidly return to baseline (less than $350 \mathrm{U} / \mathrm{L}$ within 24-48 h). While the substantial elevations in the activity of this enzyme from several thousand to hundreds of thousands IU/L may occur with rhabdomyolysis [11].

Elevations in LDH usually occur in horses with rhabdomyolysis, myocardial necrosis, and/or hepatic necrosis. Therefore, concurrent measurement of serum CK is necessary to the rhabdomyolysis cases [11, 12].

Aspartate aminotransferase (AST), is a larger molecular weight protein that has the activity in the skeletal and cardiac muscle as well as the liver, red blood cells, and other tissues. Elevations in AST are not specific for myonecrosis, it could be elevated as a result of hemolysis or muscle, liver, or other organ damage. AST activity rises more slowly in response to myonecrosis than does $\mathrm{CK}$ and peaking between 12 and $24 \mathrm{~h}$ after the insult. In addition, AST is cleared slowly and may persist for 2-3 weeks after rhabdomyolysis $[11,12]$. Combined elevations in CK and AST indicate relatively recent or active muscle necrosis, while the persistent elevation in serum CK indicates that myonecrosis is likely to be continuing. Elevated serum AST level accompanied by decreasing or normal CK level indicates that myonecrosis has ceased [11].
In Egypt, in spite of the considerable range of techniques such as many transplant rice seedling machines may be used. Farmers transplant rice seedlings in fields by the hand with the help of their draft horses, as horses carry seedlings and walk in the flooded field. Walking in the flooded field is so difficult and the work may last for one to two days/field.

Since rhabdomyolysis is being a repeated problem during rice seedling seasons every year, the present study aimed to evaluate the role of serum muscular enzymes in the determination of workloads in healthy horses and those with exertional rhabdomyolysis in rice seedlings seasons.

\section{Materials and Methods}

\section{Ethical approve}

All procedures used in the present study were approved by the Committee of Animal Welfare and Research Ethics, Faculty of Veterinary Medicine, Zagazig University, Egypt. Animals grouping and study description

Twenty-one horses (10 females and 11 males from 2-6 years old) were included in the present study, of which 10 clinically healthy horses (5 females and 5 males) were assessed under field conditions during rice seedling season. Horses were examined and sampled four times/ day work. Eleven horses (6 females and 5 males) with exertional rhabdomyolysis (during 4 successive rice seedling seasons, 2014 to 2017) under rice seedling workload were examined and sampled on admission (2$16 \mathrm{~h}$ of the onset of the clinical signs). The rhabdomyolysis cases were admitted to Veterinary Medical Teaching Hospital, Faculty of Veterinary Medicine, Zagazig University, Egypt or to some private clinics. Horses were belonged to villages in Dakhalia and Sharkia Governorates.

\section{Study conditions}

The season of rice nurseries usually starts at the end of May until the end of June every year. Commencement of the work in rice seedling transplant is usually in the early morning, between 5-6 am and ends in the evening. Horsees walk in the flooded field, in hot and humid weather, to transplant rice seedlings. Unexperienced owners usually keep 
their horses on carbohydrate-rich diet with or without a period of rest before the work.

\section{Clinical examination}

Complete history, thorough physical and clinical examinations were done according to Kelly [13].

\section{Sampling}

Blood samples were collected 4 times/day work from the clinically healthy horses; prework, during the work, $4 \mathrm{~h}$ post work and $12 \mathrm{~h}$ post, while animals with exertional rhabdomyolysis were sampled once on admission (2-16 $\mathrm{h}$ from the beginning of the symptoms). Blood samples were collected via jugular vein puncture into tubes without anticoagulant. The tubes were centrifuged at $3,000 \mathrm{rpm}$ for $15 \mathrm{~min}$ for serum separation, frozen at $-20^{\circ} \mathrm{C}$ till analysis.

\section{Measurement of serum muscular enzymes}

Concentrations of serum creatine kinase (CK), lactate dehydrogenase (LDH), and aspartate aminotransferase (AST) were measured by a spectrophotometer using commercially available kits (model Slim SEAC, Florence, Italy) according to manufacturers' instructions.

\section{Statistical analysis}

Data were statistically analyzed by a software program (SPSS, version 16) using One- way ANOVA to compare between the healthy horses in 4 periods and exertional rhabdomyolysis cases. Mean values \pm SE for each parameter were estimated. Results were considered statistically significant at $\mathrm{P}<0.05$ [14].

\section{Results}

The recorded temperature, pulse and respiration rates in healthy horses and those with rhabdomyolysis are summarized in Table 1. No abnormalities in healthy horses were detected during different times of clinical examination. All horses have commenced the work with good performance. During the work, there were no apparent problems and they successfully completed the work. Horses with exertional rhabdomyolysis admitted with the history of either being of poor performance, exhausted and did not complete the work without other overt signs. Other horses commenced the work normally for few hours after that stiffness and reluctance to move were observed.

In the healthy horses, pulse rate, respiration rate and rectal temperature significantly increased $(\mathrm{P} \leq 0.01$ or 0.05$)$ during the workload (38.20 $\pm 2.37 \mathrm{beat} / \mathrm{min}, 17.00 \pm 0.45$ breath/min and $37.90 \pm 0.07^{\circ} \mathrm{C}$, respectively) in comparison to the pre-workload values $(30.80 \pm 0.86$ beat $/ \mathrm{min}, 11.20 \pm 0.58$ breath $/ \mathrm{min}$ and $37.50 \pm 0.04^{\circ} \mathrm{C}$ respectively). These vital signs were on their way to the normal values at 4 and $12 \mathrm{~h}$ post-work. Horses with the exertional rhabdomyolysis showed significant increase $(\mathrm{P} \leq 0.01$ or 0.05$)$, comparable to healthy horses at different times, in heart rate $(53.20 \pm 2.92 \mathrm{beat} / \mathrm{min})$, rectal temperature $\left(38.46 \pm 0.26^{\circ} \mathrm{C}\right)$ and respiratory rate $(13.80 \pm 0.37 \mathrm{breath} / \mathrm{min})$ on admission.

Table 1: Alterations in the vital signs in the healthy horses and exertional rhabdomyolysis cases

\begin{tabular}{|c|c|c|c|c|c|c|c|c|c|}
\hline & \multicolumn{3}{|c|}{ Pulse rate (beat/min) } & \multicolumn{3}{|c|}{$\begin{array}{l}\text { Respiration rate } \\
\text { (breath/min) }\end{array}$} & \multicolumn{3}{|c|}{ Rectal temperature $\left({ }^{\circ} \mathbf{C}\right)$} \\
\hline & \multirow{2}{*}{ Mean $\pm \mathrm{SE}$} & \multicolumn{2}{|c|}{ Range } & \multirow{2}{*}{ Mean $\pm \mathrm{SE}$} & \multicolumn{2}{|c|}{ Range } & \multirow{2}{*}{ Mean \pm SE } & \multicolumn{2}{|c|}{ Range } \\
\hline & & Min. & Max. & & Min. & Max. & & Min. & Max. \\
\hline \multicolumn{10}{|l|}{ Healthy horses } \\
\hline Pre-workload & $30.80 \pm 0.86^{\mathrm{c}}$ & 28.00 & 33.00 & $11.20 \pm 0.58^{\mathrm{c}}$ & 10.00 & 13.00 & $37.50 \pm 0.04^{c}$ & 37.40 & 37.60 \\
\hline During workload & $38.20 \pm 2.37^{\mathrm{b}}$ & 32.00 & 44.00 & $17.00 \pm 0.45^{\mathrm{a}}$ & 16.00 & 18.00 & $37.90 \pm 0.07^{\mathrm{b}}$ & 37.70 & 38.10 \\
\hline $4 \mathrm{~h}$ post-workload & $33.40 \pm 0.87^{b c}$ & 32.00 & 38.00 & $12.60 \pm 1.29^{\mathrm{bc}}$ & 10.00 & 17.00 & $37.62 \pm 0.06^{b c}$ & 37.50 & 37.80 \\
\hline $12 \mathrm{~h}$ post workload & $31.80 \pm 0.80^{\mathrm{c}}$ & 30.00 & 34.00 & $11.60 \pm 0.51^{\mathrm{bc}}$ & 10.00 & 13.00 & $37.48 \pm 0.04^{\mathrm{c}}$ & 37.40 & 37.60 \\
\hline Rhabdomyolysis horses & $53.20 \pm 2.92^{\mathrm{a}}$ & 47.00 & 63.00 & $13.80 \pm 0.37^{\mathrm{b}}$ & 13.00 & 15.00 & $38.46 \pm 0.26^{\mathrm{a}}$ & 37.80 & 39.20 \\
\hline Sig. & \multicolumn{3}{|l|}{$* *$} & & \multicolumn{3}{|l|}{$* *$} \\
\hline
\end{tabular}

SE: Standard Error, Min.: Minimum, Max.: Maximum, Sig.: Significance

All data having different letters are differ significantly at $\mathrm{p}<0.05$ 
Table 2: Serum muscular enzymes activities in healthy horses and exertional rhabdomyolysis cases

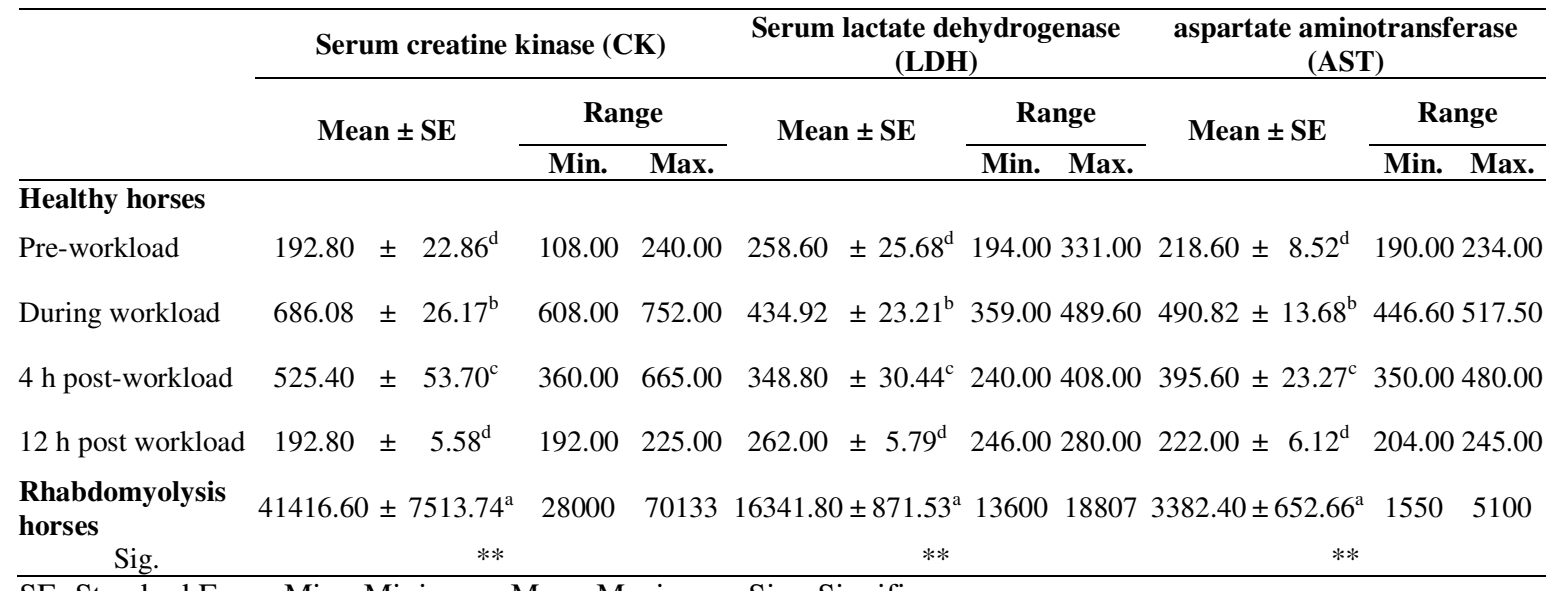

SE: Standard Error, Min.: Minimum, Max.: Maximum, Sig.: Significance

All data having different letters are differ significantly at $\mathrm{p}<0.05$

The clinical alteration observed in rhabdomyolysis horses varied in the severity between individuals: poor performance without overt signs ( 2 of 11), stiffness, short strides, eventually inability to move forward when forced to walk and firm, painful palpation of the gluteal muscle (9 of 11), sweating ( 2 of 11) and dark brown urine (5 of 11) as shown in Figure 1.

It is worthy to mention that the risk factors for the occurrence of rhabdomyolysis in this study were nervous temperament horses, younger ages (2-4 years old), being females, hoof affections and with full carbohydrate ration during rest period (Figure 2).

The results of serum muscular enzymes are summarized in Table 2. Serum CK, LDH and AST activities in healthy horses were significantly higher $(\mathrm{P} \leq 0.001)$ during the workload $(686.08 \pm 26.17 \mathrm{U} / \mathrm{L}, 434.92 \pm 23.21$ $\mathrm{U} / \mathrm{L}$ and $490.82 \pm 13.68 \mathrm{U} / \mathrm{L}$, respectively) and $4 \mathrm{~h}$ post-workload $(525.40 \pm 53.70 \mathrm{U} / \mathrm{L}$, $348.80 \pm 30.44 \mathrm{U} / \mathrm{L}$ and $395.60 \pm 23.27 \mathrm{U} / \mathrm{L}$, respectively). Anywhere, the workload multiplied the activity of these enzymes (CK, LDH and AST), when measured during workload and $4 \mathrm{~h}$ post-workload, as compared with the pre-workload $(192.80 \pm 22.86 \mathrm{U} / \mathrm{L}$, $258.60 \pm 25.68 \mathrm{U} / \mathrm{L}$ and $218.60 \pm 8.52 \mathrm{U} / \mathrm{L}$, respectively) and $12 \mathrm{~h}$ post-workload (192.80 $\pm 5.58 \mathrm{U} / \mathrm{L}, 262.00 \pm 5.79 \mathrm{U} / \mathrm{L}$ and $222.00 \pm$ $6.12 \mathrm{U} / \mathrm{L}$, respectively). Serum muscular enzymes activities in rhabdomyolysis cases revealed great abnormalities. Serum CK, LDH and AST levels were $41416.60 \pm 7513.74 \mathrm{U} / \mathrm{L}$, $16341.80 \pm 871.53 \mathrm{U} / \mathrm{L}$ and $3382.40 \pm 652.66$ $\mathrm{U} / \mathrm{L}$, respectively. While the reference ranges were 100 to $350 \mathrm{U} / \mathrm{L}$ for $\mathrm{CK}, 150$ to $450 \mathrm{U} / \mathrm{L}$ for $\mathrm{LDH}$ and serum 100 to $600 \mathrm{U} / \mathrm{L}$ for AST.

\section{Discussion}

Horses have the greatest capacity for physical work but physical exercise usually produces physiological responses and metabolic adaptations [15]. In the present study, the healthy horses (under work load of rice seedlings transplant) had higher pulse rate, respiration rate, and rectal temperature during the workload in comparison to the preworkload state, and their rates were on their way back to normal in $4 \mathrm{~h}$ post-work. Unlike the racing horses that under routine training, physical exercise had a lower effect on the vital signs, i.e. lower heart rate was used as a determinant of horse fitness in response to the strenuous effort $[16,17]$. Therefore, when we lose the basics of the horses training and work (adaptation for the work and nutrition) rhabdomyolysis could be expected.

The development of ER was a common and catastrophic occurrence during the $19^{\text {th }}$ century and early part of the $20^{\text {th }}$ century before cars replaced draft and carriage horses as a means of transportation. Mortality rates as high as $50 \%$ were reported in some clinics $[18,19]$. 


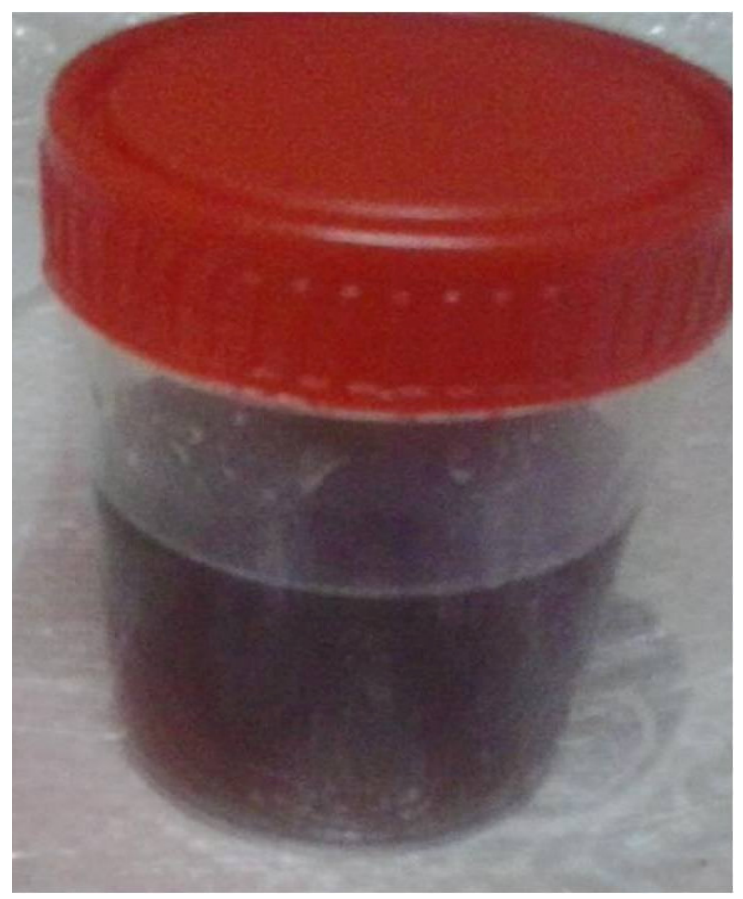

Figure 1: Dark brown urine in exertional rhabdomyolysis cases.

In the present study, poor performance recorded in two rhabdomyolysis cases may be tentatively attributed to inadequate training for this work, but the elevated muscular enzymes are determinates for rhabdomyolysis, such cases may be named as sub-clinical rhabdomyolysis. Consequently, diagnosis of ER depending only on the clinical signs may be challenging, because clinical signs vary in the severity from mild stiffness during or after work with poor performance to a marked reluctance to move, myoglobinuria, hard, swollen and painful gluteal muscles, beside the elevated pulse, respiratory rates and rectal temperature. Similar clinical findings were previously reported $[1,6,9,20]$. Regarding to the risk factors, the obtained results were comparable to those previously obtained by other authors [21,22].

Severe exercise can result in serious health problems. The release of serum muscular enzymes, including creatine kinase (CK), aspartate transaminase (AST), and lactate dehydrogenase (LDH), is considered to be a suitable indicator for the muscle injury during exercise [23]. Studies have demonstrated the extent of hematobiochemical alteration in horses depends on several factors: type of exercise, the intensity of work (strength, duration, and frequency) and individual variation [24]. On harmony with this statement, the highly significant increase in the activities of $\mathrm{CK}, \mathrm{LDH}$, and AST observed in healthy horses during workload and $4 \mathrm{~h}$ postwork indicates the intensity of the work and workload can easily double the activity of the enzymes compared to the activity measured at rest [25]. Such increase in the serum muscular enzymes could be related to the increased skeletal muscle membrane leakage following strenuous exercise [26-29]. Meanwhile, the serum muscular activities return to normal (pre-workload) at $12 \mathrm{~h}$ post-workload. This suggested that the sampling at least 12-24 $\mathrm{h}$ after exercise can be helpful in the diagnosis of muscle damage. This could be helpful to distinguish horses showing a normal physiological response to exercise and those with abnormal or pathologic response to the workload [27]. Serum CK peaks within 4 to 6 $\mathrm{h}$ after intense exercise and its half-life is 90$120 \mathrm{~min}$, that makes $\mathrm{CK}$ a reliable indicator for detection and monitoring of muscle damage in horses [29-31]. This is confirmed by field observations, that following a shortterm effort; the increase in $\mathrm{CK}$ is smaller than horses competing in endurance [32-34]. 


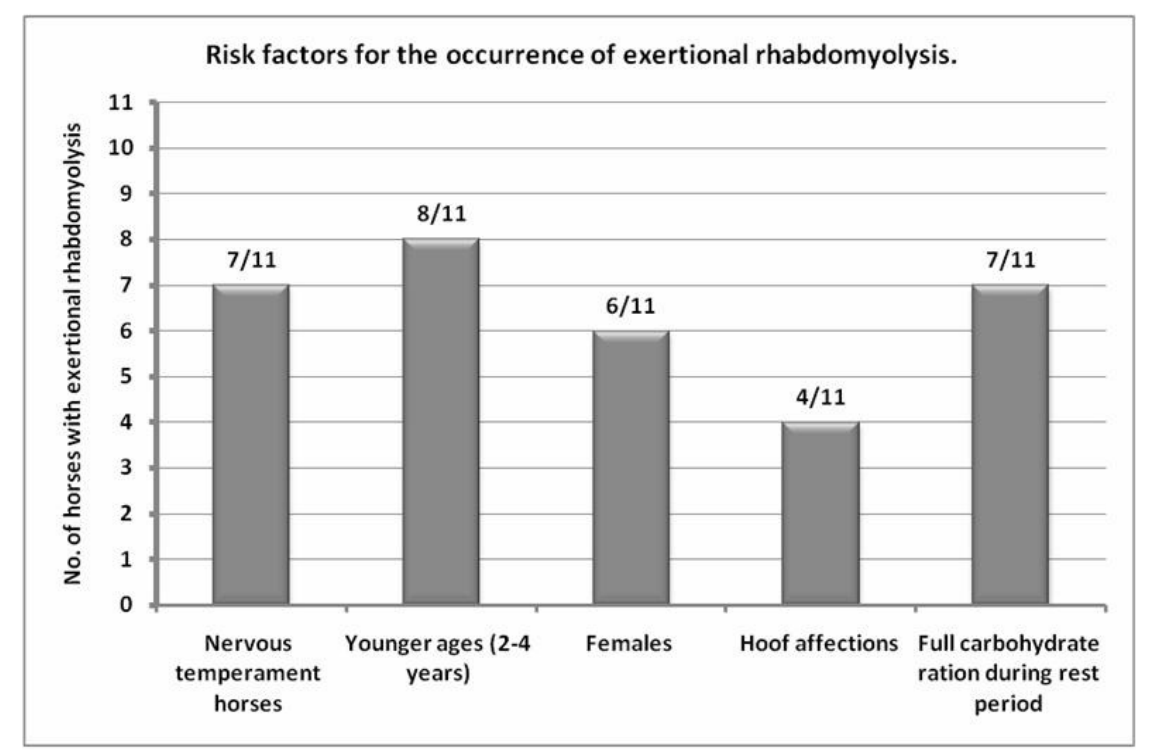

Figure 2: Risk factors for the occurrence of exertional rhabdomyolysis.

Our results regarding the serum muscular enzymes in the rhabdomyolysis cases were similar to those reported by El-Ashker [6], in draft horses in rice seedlings season. The author recorded significant increase in serum CK, LDH and AST in mild $(56.103 \pm 160$, $14.741 \pm 1679$ and $2819.4 \pm 604$ IU/L, respectively) and severe cases of rhabdomyolysis $\quad(267.906 \pm 11737$, $23.373 \pm 1440$ and $6432.2 \pm 823$ IU/L, respectively).

In these instances, the over-exertion caused by increased work intensity without a foundation for such type of work is the base for the occurrence of the disease. Overexertion is a well-described cause of ER in polo horses, $81 \%$ of cases with ER was attributed to overexertion and $30 \%$ occurring after a day of rest [35].

There are large varieties of causes and types for rhabdomyolysis, all leading to muscle breakdown but they seem to lead to a final common feature, which is the breakdown of muscle tissue, destruction of the myocyte and distribution of its components into the circulation. Subsequently, myoglobin, CK, LDH and AST release into the circulation. Besides the old theories in rhabdomyolysis, recent studies indicated that oxidative stress during exercise could be contributed to the formation of oxidative fiber myolysis [36-39]. Free radicals and other reactive oxygen species (ROS) were expected in the pathogenesis of exertional rhabdomyolysis in draft horses used in rice seedlings season [9], the author recorded higher values of lipid peroxides, malondialdehyde, nitric oxide and lower values of antioxidant enzymes in fatal cases of rhabdomyolysis in comparison with both control horses and survivor cases.

\section{Conclusion}

Exertional rhabdomyolysis is common at the beginning of rice seedling season in draft horses. In order to obtain better fitness and performance during the season, it is necessary to increase the workload before the season. Feed should be adjusted according to the work done, not according to the work will be done with a period of adaptation for such work and before starting harder work, high fiber and low starch diet is effective to minimize the occurrence of this condition.

\section{Conflict of interest}

The author declares no conflict of interest.

\section{References}

[1] Quist, E.M.; Dougherty, J.J.; Chaffin, M.K. and Porter, B.F. (2011): Diagnostic 
Exercise: Equine Rhabdomyolysis. Vet Pathol, 48(6): E52-E58.

[2] Freestone, J.F. and Carlson, G.R. (1991): Muscle disorders in the horse: a retrospective study. Equine Vet J, 23(2): 86-90.

[3] Sponseller, B.T.; Valberg, S.J.; TennentBrown, B.S.; Foreman, J.H.; Kumar, P. and Timoney, J.F. (2005): Severe acute rhabdomyolysis associated with Streptococcus equi infection in four horses. J Am Vet Med Assoc, 227(11): 18001807.

[4] Valentine, B.A. and Cooper, B.J. (2005): Incidence of polysaccharide storage myopathy: necropsy study of 225 horses. Vet Pathol, 42(6): 823-827.

[5] Hunt, L.M.; Valberg, S.J.; Steffenhagen, K. and McCue, M.E. (2008): An epidemiologic study of myopathies in warmblood horses. Equine Vet J, 40(2): 171-177.

[6] El-Ashker, M.R. (2011): Acute kidney injury mediated by oxidative stress in Egyptian horses with exertional rhabdomyolysis. Vet Res Commun, 35(5): 311-320.

[7] Valentine, B.A.; de Lahunta, A.; Divers, T.J.; Ducharme, N.G. and Orcutt, R.S. (1999): Clinical and pathologic findings in two draft horses with progressive muscle atrophy, neuromuscular weakness, and abnormal gait characteristic of shivers syndrome. J AmVet Med Assoc, 215(11): 1661-1665.

[8] Valberg, S. (1998): Tying-up causes and treatment. Proc North Am Vet Conf, 12: 1049-1050.

[9] El-Ashker, M.R. (2012): Diagnostic efficiency of selected biochemical variables to predict the clinical outcome of exertional rhabdomyolysis in Egyptian draft horses. Comp Clin Pathol, 21(5): 1103-1108.

[10] Cardinet, G.H. (1997): Skeletal muscle function. In Kaneko, J.J.; Harvey, J.W. and Bruss, M.L. editors. Clinical biochemistry of domestic animals. New York: Academic press. 407-440.

[11] Valberg, S.; Jönsson, L.; Lindholm, A. and Holmgren, N. (1993): Muscle histopathology and plasma aspartate aminotransferase, creatine kinase and myoglobin changes with exercise in horses with recurrent exertional rhabdomyolysis. Equine Vet J, 25(1): 1116.

[12] Kobluk, C.N.; Ames, T.R. and Geor, R.J. editors (1995): Clinical evaluation of muscle and muscular disorders. The Horse: Diseases and Clinical Management. Philadelphia: W.B. Saunders. 1314-1318.

[13] Kelly, W.R. (1974): Veterinary clinical diagnosis. $2^{\text {nd }}$ edition. London: Baillere Tindall $25 \mathrm{p}$.

[14] Duncan, D.B. (1955) : Multiple range and multiple F test Biometrics, 11: 1- 42

[15] Arfuso, F.; Giannetto, C.; Giudice, E.; Fazio, F. and Piccione, G. (2016): Dynamic modulation of platelet aggregation, albumin and nonesterified fatty acids during physical exercise in Thoroughbred horses. Res Vet Sci, 104: 86-91.

[16] Cottin, F.; Barrey, E.; Lopes, P. and Billat, V.L. (2006): Effect of fatigue during five successive heats $(800 \mathrm{~m}$ at high velocity) and recovery runs on heart rate variability in Standardbreds. Proceeding of the $7^{\text {th }}$ International Conference on Equine Exercise Physiology, Fontainebleau, France 68 p.

[17] Bashir, A. and Rasedee, A. (2009): Plasma catecholamine, sweat electrolytes and physiological responses of exercised normal, partial, anhidrotic and anhidrotic horses. Am J Anim Vet Sci, 4(1): 26-31.

[18] Carlström, B. (1931): Uber die atiologie und pathogenese der kreuzlähme des pferdes (Haemoglobinaemia paralytica). Acta Physiologica, 62(2): 1-69. 
[19] Carlström, B. (1932): Uber die atiologie und pathogenese der kreuzlahme des pferdes (Haemaglobinaemia paralytica). Acta Physiologica, 63(1): 164-212.

[20] Harris, P.A. (1998): Equine rhabdomyolysis syndrome. In Watson, T. editor. Metabolic and Endocrine Problems of the Horse. London: W.B. Saunders. 75-99.

[21] Harris, P.A. (1991): The equine rhabdomyolysis syndrome in the United Kingdom: epidemiological and, clinical descriptive information. Br Vet J, 147(4): 373-384.

[22] Macleay, J.M.; Sorum, S.A.; Valberg, S.J.; Marsh, W.E. and Sorum, M.D. (1999): Epidemiological analysis of factors influencing exertional rhabdomyolysis in Thoroughbreds. Am J Vet Res 60(12): 1562 -1566.

[23] Da Cás, E.L.; Rosauro, A.C.; Silva, C.A.M. and Brass, K.E. (2000): Concentração sérica das enzimas creatinoquinase, aspartato aminotransferase ehidrogenase láctica em eqüinos da raça crioula. Cienc. Rural, 30(4): 625-629.

[24] Krumrych, W. (2006): Variability of clinical and haematologic indices in the course of training exercise in jumping horses. Bull Vet Inst Pulawy. 50(3): 391396.

[25] Art, T.; Amory, H.; Desmecht, D. and Lekeux, P. (1990): Effect of show jumping on heart rate, blood lactate and other plasma biochemical values. Equine Vet J, 22(S9): 78-82.

[26] Assenza, A.M.; Piccione, G. and Caola, G. (1996): Parametri ematochimici ed attività enzimatiche nel cavallo dopo prova di ostacoli, Atti. SIS Vet, 50: 6768.

[27] Harris, P.A.; Snow, D.H.; Greet, T.R. and Rossdale, P.D. (1990): Some factors influencing plasma AST/CK activities in thoroughbred racehorses. Equine Vet J, 22(S9): 66-71.
[28] Janicki, B.; Kochowicz, A.; Buzała, M. and Krumrych, W. (2013): Variability of selected biochemical parameters in young stallions during the 100-day performance test. J Equine Vet Sci, 33(12): 1136-1141.

[29] Siciliano, P.D.; Lawrence, L.M.; Danielsen, K.; Powell, D.M. and Thompson, K.N. (1995): Effect of conditioning and exercise type on serum creatine kinase and aspartate aminotransferase activity. Equine Vet J, 27 (S 18): 243-247.

[30] Harris, P.A.; Marlin, D.J. and Gray, J. (1998): Plasma aspartate aminotransferase and creatine kinase activities in Thoroughbred racehorses in relation to age, sex, exercise and training. Vet J, 155(3): 295-304.

[31] Chaney, K.; MacLeay, J.M.; Enns, R.M.; Al-Sobayil, F.; Kawcek C. and Frisbie, D. (2004): Effects of induced lameness via carpal osteochondral fragmentation on plasma creatine kinase activity in horses. J Equine Vet Sci, 24(12): 531534.

[32] Anderson, M.G. (1975): The influence of exercise on serum enzyme levels in the horse. Equine Vet J, 7(3): 160-165.

[33] Jagrič, M.S.; Nemec, S.A.; Zrimšek, P.; Kramarič, P.; Kos, K.V.; Vovk, T. and Kobal, S. (2012): Plasma malondialdehyde, biochemical and haematological parameters in Standardbred horses during a selected field exercise test. Acta Vet-Beograd, 62(1): 53-65.

[34] Gondin, M.R.; Foz, N.S.B.; Pereira, M.C.; Flagliari, J.J.; Orozco, C.A.G.; D'Angelis, F.H.F.; Queiroz-Neto A. and Ferraz, G.C. (2013): Acute phase responses of different positions of highgoal (elite) polo Ponies. J Equine Vet Sci, 33(11): 956-961.

[35] McGowan, C.M.; Posner, R.E. and Christley, R.M. (2002): Incidence of exertional rhabdomyolysis in polo horses 
in the USA and the United Kingdom in the 1999/2000 season. Vet Rec, 150(17): 535-537.

[36] Matsuki, N.; Tamura, S.; Ono, K.; Watari, T.; Goitsuka, R.; Yamanobe, A.; Hiraga, A.; Kubo, K.; Takagi, S.; Hasegawa, A. and Suzuki, N. (1991): Exercise-induced phospholipids degradation in the equine skeletal muscle and erythrocytes. J Vet Med Sci, 53(6): 1001-1007.

[37] Mills, P.C.; Smith, N.C.; Casas, I.; Harris, P.; Harris, R.C. and Marlin, D.J. (1996): Effects of exercise intensity and environmental stress on indices of oxidative stress and iron homeostasis during exercise in the horse. Eur $\mathbf{J}$ Appl Physiol Occup Physiol, 74(1-2): 60-66.
[38] Williams, C.A.; Kronfeld, D.S.; Hess, T.M.; Saker, K.E.; Waldron, J.N.; Crandell, K.M.; Hoffman, R.M. and Harris, P.A. (2004): Antioxidant supplementation and subsequent oxidative stress of horses during an 80$\mathrm{km}$ endurance race. J Anim Sci, 82(2): 588-594.

[39] DeWitt, J.; Lamprech, E. and Williams, C. (2007): Nitric oxide concentration in plasma and synovial fluid of intensely exercising horses. Equine Sci Soc Proc 20: 64-65.

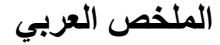

دور الإتزيمات العضلية في تثخيص انحلال الربيدات ما بعد الإجهاد في خيول الجر المستخدمة في نقل شتلات الأرز

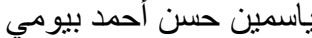
قسم طب الحيوان ( مادة الأمر اض الباطنه)- كلبة الطب البيطري- جامعة الزقازيق

استهدف هذا العمل دراسة دور الإنزيمات العضلية في تقييم عبء العمل في الحيوانات السليمة وكذلك تتخيص الحالات التي

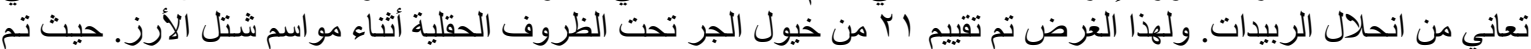

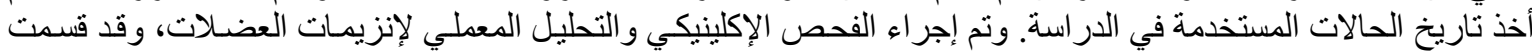

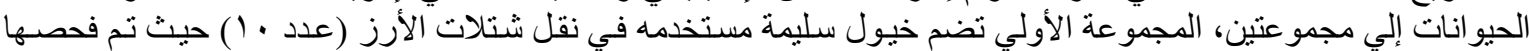

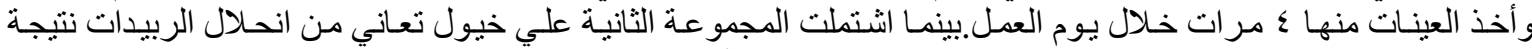

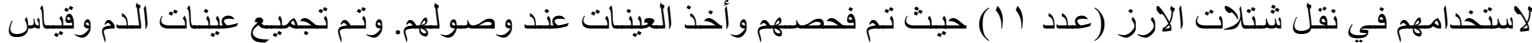

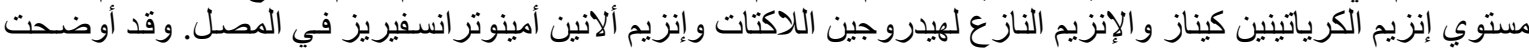

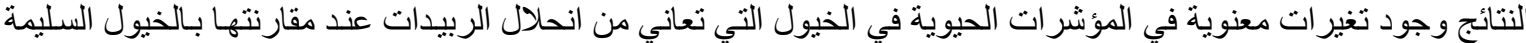

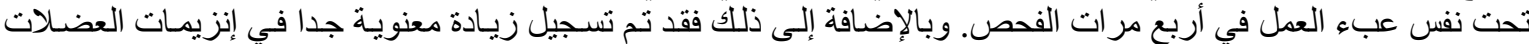

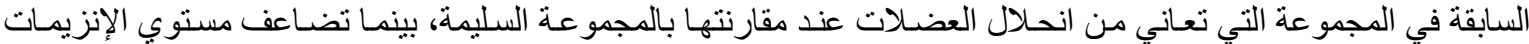

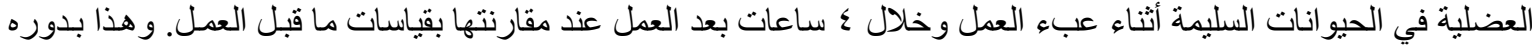
يعكس العبء الكبير علي الحيوانات السليمة أثناء شتل الأرز.
} 